\title{
The Protective Effects of water Extracts of ZoaGumHwan (ZGH) on the Oxidized LDL-induced Monocyte Adhesion to Human Umbilical Vein Endothelial Cells
}

\author{
Yu Jin Ko ${ }^{1}$, Byung Chul Park ${ }^{1}$, Jong Suk LeE ${ }^{1}$, Su-Young PARK ${ }^{1}$, Heung Mook SHIN ${ }^{2}$, \\ Bong Kyu Yoo ${ }^{1}$, and Jung-Ae KIM ${ }^{1, *}$ \\ ${ }^{1}$ College of Pharmacy, Yeungnam University, Gyeongsan 712-749, Korea \\ ${ }^{2}$ Department of Physiology, College of Oriental Medicine, Dongguk University, Kyoungju 780-714, Korea
}

(Received July 27, 2007; Accepted Sep 14, 2007)

\begin{abstract}
It is well known that oxidized low-density lipoprotein (oxLDL) is the most characterized humoral factor that plays an important role in the pathogenesis of atherosclerosis. The water extract of the Korean herbal remedy, ZoaGumHwan (ZGH), which is composed of roots of Coptis chinensis Franch and fruits of Evodia officinalis Dode with the ratio of 6 to 1, reduced the in vitro oxidation of low density lipoproteins (LDL). Also, the ZGH extract and berberine, one of the major components of ZGH, significantly prevented oxLDL-induced adhesion of monocytes to human umbilical vein endothelial cells (HUVEC). Furthermore, the ZGH water extract and berberine decreased oxLDL-induced expression of CC chemokine receptor 2 (CCR2), a dominant monocyte chemotaxis receptor, in U937 human monocytic cells. The protective effects of the ZGH water extract and berberine were similar to those of simvastatin, an effective lipid-lowering drug. The results suggest that Korean herbal remedy, ZGH, seems to have protective effect against oxLDL-induced monocyte chemoattractant protein (MCP)-1/ CCR2-dependent monocyte recruitment onto endothelial cells.
\end{abstract}

Keywords $\square$ oxidized low density lipoprotein, monocyte adhesion, berberine, ZoaGumHwan, monocyte chemoattaractant protein-1, CC chemokine receptor 2

\section{INTRODUCTION}

Vascular endothelial cells play a pivotal role in the maintenance of vessel wall integrity. Oxidized low-density lipoprotein (oxLDL) has been implicated to induce vascular endothelial dysfunction in the process of atherogenesis which has a characteristic of an atherosclerotic plaque formation. The crucial step to cause atherosclerotic plaque formation is a focal accumulation of monocytes of which process includes monocyte adhesion, migration, and infiltration.

Monocyte chemoattractant protein (MCP)-1, a 14 kDa glycoprotein of the $\mathrm{CC}$ chemokine family, is a potent chemoattractant for monocyte recruitment (Navab et al., 1991; Adams and Lloyd., 1997), and it is expressed by various cell types including human umbilical vein endothelial cells (HUVEC) (Sica et al., 1990). MCP-1 has been found as one of the key factors to start the inflammatory process in atherogenesis (Terkeltaub et

*Corresponding author

Tel: $+82-53-810-2816, \quad$ Fax: $+82-53-810-4654$

E-mail: jakim@yu.ac.kr (J.A. Kim) al., 1998; Navab et al., 1991). Not only in vitro cell system, but also in atherosclerotic patients, MCP-1 mRNA expression has been detected in endothelial cells, macrophages, and vascular smooth muscle cells in atherosclerotic arteries (Seino et al., 1995). Therefore, MCP-1 is a critical factor to initiate atherosclerotic lesions.

Unlike most $\mathrm{CC}$ chemokines that bind to $\mathrm{CC}$ chemokine receptor (CCR)-1 through CCR8, MCP-1 binds only to CCR2 (Charo et al., 1994; Boring et al., 1998; Kurihara and Bravo, 1996). Therefore, the MCP-1/CCR2 binding is the important step of monocyte recruitment and seems to play a primary role in many inflammatory states of vessels. (Takeya et al., 1993; Yang et al., 2004; Kaikita et al., 2004).

ZoaGumHwan (ZGH), a Korean herbal remedy, is composed of roots of Coptis chinensis Franch and fruits of Evodia officinalis Dode with a ratio of 6 to 1 . Coptis chinensis is a widely used herb in traditional chinese medicine for the treatment of inflammation related diseases. As one of the major alkaloids in Coptis chinensis, berberine has a strong antiinflammatory activity. Berberine has been shown to have vasorelaxing and anti-proliferating effects (Ko et al., 2000) and 
to reduce serum low density lipoproteins (LDL) cholesterol levels in both hamsters and human patients (Kong et al., 2004). In addition, we reported the inhibitory effects of ZGH water extract and berberine on angiotensin (Ang) II-induced endothelial inflammation (Ko et al., 2007). It has been suggested that berberine is useful for treating cardiovascular disease such as hypertension and atherosclerosis (Lau et al., 2001; Hong et al., 2002).

In spite of all the studies, the effects of berberine and the extract of berberine-containing plants on the oxLDL-induced endothelial expression of adhesion molecules have not been studied. In the present study, we examined whether ZGH water extract and berberine prevents oxLDL-induced expression of inflammatory genes and monocyte adhesion to endothelial cells.

\section{MATERIALS AND METHODS}

\section{Preparation of ZGH water extract}

ZGH is a mixture of roots of Coptis chinensis Franch and fruits of Evodia officinalis Dode, which was obtained from the Oriental Herbal Center (OHC) of the Oriental Medical Hospital of Dongguk University College of Oriental Medicine (Kyoungju, Korea). For water extraction, ZGH (210 g) was mixed with $1,500 \mathrm{ml}$ of distilled water and extracted under reflux for $3 \mathrm{~h}$ at $100^{\circ} \mathrm{C}$. The extract was filtered with a Whatman paper filter. The filtrate was concentrated by a vacuum evaporator, freeze dried, and preserved at $-20^{\circ} \mathrm{C}$ until use. The yield of the dried extract was approximately $18.5 \mathrm{~g} / 1$. The extract was suspended in distilled water, and used for experiments.

\section{Cell Culture}

HUVECs were purchased from Clonetics (San Diego, CA). HUVECs were grown on $0.2 \%$ gelatin coated flask with EBM2 medium supplemented with $2 \%$ fetal bovine serum (FBS), ascorbic acid, hydrocortisone, human fibroblast growth factor (hFGF), vascular endothelial growth factor (VEGF), human epidermal growth factor (hEGF), long $\mathrm{R}$ insulin-like growth factor-1 ( $\mathrm{R}^{3}$-IGF-1), gentamicin sulfate (GA-1000) and heparin. HUVECs between passage 2 and 6 were used in the experiments.

U937 cells were maintained in a RPMI 1640 medium supplemented with $10 \% \mathrm{FBS}, 1 \mathrm{mM}$ sodium pyruvate, $200 \mathrm{IU} / \mathrm{ml}$ penicillin and $200 \mu \mathrm{g} / \mathrm{ml}$ of streptomycin. Culture medium was replaced every other day. After attaining confluence, the cells were subcultured by splitting 1:5 ratio.

\section{Isolation of LDL and generation of oxLDL}

Blood from healthy volunteers was obtained by venipunc- ture and collected in evacuated tubes. Ethylene diamine tetraacetate (EDTA) was used as an anticoagulant and antioxidant when samples were intended for LDL isolation. Blood was centrifuged at $800 \mathrm{x}$ g at $4^{\circ} \mathrm{C}$ for $15 \mathrm{~min}$ and then, the separated plasma was employed to prepare LDL $(\mathrm{d}=1.019$ - $1.063 \mathrm{~g} / \mathrm{ml})$ by sequential flotation ultracentrifugation at $10^{\circ} \mathrm{C}$ as previously described (Ramos et al., 1995). The isolated LDL was dialyzed for $48 \mathrm{hr}$ against $10 \mathrm{mM}$ sodium phosphate buffer $\mathrm{pH} 7.4$ containing $150 \mathrm{mM} \mathrm{NaCl}$ and $0.1 \mathrm{mM}$ EDTA at $4^{\circ} \mathrm{C}$ and used within two weeks. The protein content of the LDL was measured by the Bradford method (Bradford, 1976) using bovine serum albumin (BSA) as standard.

To obtain oxLDL, LDL oxidation was done by incubating with $10 \mu \mathrm{M}$ CuSO 4 in $10 \mathrm{mM}$ sodium phosphate buffer at 37 ${ }^{\circ} \mathrm{C}$ for $20 \mathrm{~h}$ and then, stopped by adding an $10 \mathrm{mM}$ EDTA solution. Oxidation of LDL was monitored by thiobarbituric acidreactive substances (TBARs) analysis (Buege and Aust, 1978).

\section{In vitro LDL oxidation study}

Isolated LDL was preincubated with $\mathrm{ZGH}$ water extract for $30 \mathrm{~min}$. LDL oxidation was initiated by adding $10 \mu \mathrm{M}$ CuSO 4 to the reaction mixture. The TBARs was determined after $20 \mathrm{~h}$. Briefly, $500 \mu \mathrm{l}$ of reaction mixture was mixed with $1 \mathrm{ml}$ of freshly prepared $20 \%$ acetate buffer ( $\mathrm{pH} 3.5$ ) containing 0.046 $\mathrm{mol} / \mathrm{l}$ thiobarbituric acid and $0.92 \mathrm{~mol} / \mathrm{l}$ trichloroacetic acid. After $30 \mathrm{~min}$ incubation at $100^{\circ} \mathrm{C}$, the samples were cooled on ice, centrifuged at $1000 \mathrm{~g}$ for $5 \mathrm{~min}$ at RT. The absorbance of the supernatant containing malondialdehyde (MDA), TBARS, was read at $532 \mathrm{~nm}$.

\section{U937 adhesion assay}

Monocyte-endothelial adhesion was evaluated using the human leukemia pro-monocytic U937 cells which were labeled with 2',7'-bis(2-carboxyethyl)-5(6)-carboxyfluorescein acethoxymethyl ester (BCECF/AM, $10 \mu \mathrm{g} / \mathrm{ml}$ ) for $1 \mathrm{~h}$ at $37^{\circ} \mathrm{C}$. HUVECs cultured in 24-well plate were pretreated with $\mathrm{ZGH}$ water extract or berberine for $30 \mathrm{~min}$ and then incubated with Ang II for an additional $3 \mathrm{~h}$. Then, HUVECs were co-incubated with BCECF/AM-prelabeled U937 cells $\left(1 \times 10^{6}\right.$ cells/well $)$ for $30 \mathrm{~min}$ at $37^{\circ} \mathrm{C}$. Non-adhering U937 cells were removed, and the cells were washed twice with PBS. A set of cells was taken and imaged by inverted microscopy connected to digital camera (TMS; Nikon, Japan), and in other sets, cells were lysed in $0.1 \%$ Triton X-100 in $0.1 \mathrm{~mol} / 1$ Tris. Fluorescence was measured by using a Fluostar optima microplate reader (BMG LABTECH GmbH, Germany) using excitation at $485 \mathrm{~nm}$ and 
emission at $520 \mathrm{~nm}$.

\section{RT-PCR (mRNA analysis)}

The total cellular RNA was isolated using Trizol reagent (Invitrogen, Carlsbad, CA) and RT-PCR was performed as previously described (Park et al., 2007). Briefly, cDNA was synthesized using a Ready-To-Go T-Primed First Strand Kit (Amersham Biosciences, USA). PCR was performed in the presence of $0.5 \mathrm{U}$ Taq DNA polymerase (Takara, Japan) using primer sets that were specific to the following: MCP-1 (5'-CCC TTC TGT GCC TGC TGC TCA T-3', 5'-TTT CCC CAA GTC TCT GTA TCT-3'; expected 300bp fragment); CCR-2 (5'GGA TTG AAC AAG GAC GCA TT-3', 5'-TCT CAC TGC CCT ATG CCT CT-5'; expected 766bp fragment); lectinlike oxLDL receptor(LOX)-1 (5'-ACA GAT CTC AGC CCG GCA ACA AGC A-3', 5'-GGG AGA CAG CGC CTC GGA CTC TAA AT-3'; expected 463bp fragment); and GAPDH (5'GGT GAA GGT CGG AGT CAA CG-3', 3'-CCA GTA GGT ACT GTT GAA AC-5'; expected 496bp fragment). The PCR products were separated on a $2 \%$ agarose gel containing ethidium bromide $(0.5 \mu \mathrm{g} / \mathrm{ml})$, visualized, and photographed using a gel documentation system (UVP, Cambridge, UK).

\section{DPPH radical scavenging assay}

To measure the antioxidant activity of the samples, free radical scavenging activity was detected using 1,1-diphenyl-2-picryl-hydroazyl (DPPH) as previously reported (Blois, 1958). Briefly, $200 \mu \mathrm{M}$ solution of DPPH in methanol was prepared. DPPH solution $(190 \mu \mathrm{l})$ was added to $10 \mu \mathrm{l}$ of sample solution, and mixed with vigorous shaking for $10 \mathrm{~s}$. After thirty minutes, the absorbance was measured at $517 \mathrm{~nm}$. DPPH radical scavenging ability was calculated following equation in which $H$ and $H_{O}$ were optical density of with and without sample, respectively.

$$
\text { Radical scavenging activity }(\%)=\left\{(1-H) / H_{0}\right\} 100
$$

\section{Data analysis}

The data are expressed as means \pm S.E.M. and were analyzed using one-way analysis of variance (ANOVA) and the Student-Newman-Keul's test for individual comparisons. $P$ values of $<0.05$ were considered statistically significant.

\section{RESULTS}

ZGH water extract and Berberine inhibitis oxLDLinduced monocyte adhesion to endothelial cells
To determine whether ZGH water extract and berberine have an inhibitory action in oxLDL-induced vascular inflammation, we first examined the effect of ZGH water extract on Ang IIinduced monocyte adhesion to endothelial cells, an initial step of monocyte recruitment, by using U937 human premonocytic cell line (Carvalho et al., 1996; Lazzarino et al., 2001). As shown in Fig. 1, oxLDL (50 $\mu \mathrm{g} / \mathrm{ml})$ stimulation for $3 \mathrm{~h}$ significantly enhanced U937 adhesion to HUVECs. ZGH water extract and berberine inhibited oxLDL-induced monocyte adhesion in a concentration-dependent manner (Fig. 1A and Fig. 1B). Since the inhibitory effect of simvastatin, a 3-

(A)

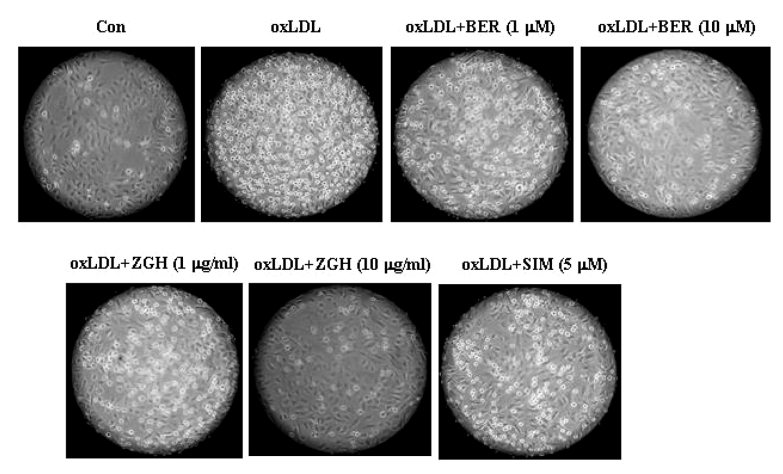

(B)

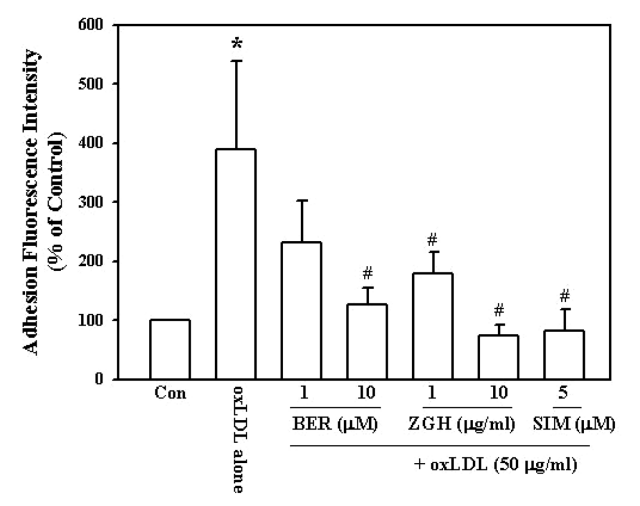

Fig. 1. Inhibitory effects of ZGH water extract and berberine on oxLDL-induced monocyte adhesion to endothelial cells. The adhesion of fluorescence-labeled U937 cells to HUVECs was detected by microscopic images (A), and quantitated by using a fluorescence-detecting microplate reader (B). HUVECs were treated with different concentrations of ZGH water extract (1 and $10 \mu \mathrm{g} / \mathrm{ml})$, berberine $(1$ and $10 \mu \mathrm{M})$, and simvastatin $(5$ $\mathrm{iM})$ for $30 \mathrm{~min}$ before oxLDL $(50 \mu \mathrm{g} / \mathrm{ml})$ treatment for $3 \mathrm{~h}$. Data are expressed as the mean \pm S.E.M. of three independent experiments. ${ }^{*} P<0.01$ compared to untreated control group. ${ }^{\sharp} P$ $<0.01$ compared to the oxLDL-treated group. 
hydroxy-3-methylglutaryl coenzyme A (HMG-CoA) reductase inhibitor, on MCP-1/CCR2-mediated monocyte recruitment has been known (Han et al., 2005), we used simvastatin as a positive control. The effect of ZGH water extract at $10 \mu \mathrm{g} / \mathrm{ml}$ concentration was similar to that of simvastatin $(5 \mu \mathrm{M})$.

ZGH water extract and berberine inhibits oxLDLinduced expressions of MCP-1 in HUVECs and CCR2 in U937 cells

Since expression level of CCR2 and MCP-1 is important in controlling the process of monocyte recruitment (Han et al., 1998; Han et al., 1999; Han et al., 2000), we examined whether ZGH water extract and berberine inhibits oxLDL-induced expression of both MCP-1 and CCR-2. The treatment with oxLDL $(50 \mu \mathrm{g} / \mathrm{ml})$ for $3 \mathrm{~h}$ significantly increased MCP-1 mRNA level in HUVECs (Fig. 2A). Similarly, CCR2 mRNA expression in U937 cells, a receptor for MCP-1, was increased by the treatment with oxLDL $(50 \mu \mathrm{g} / \mathrm{ml})$ for $3 \mathrm{~h}$ (Fig. $2 \mathrm{~B})$. However, co-treatment with ZGH water extract and berberine significantly suppressed the oxLDL-increased MCP-1 and CCR2 mRNA, which corresponds to its suppressive effect on the adhesion of U937 to HUVECs. The inhibitory effects of ZGH water extract and berberine were similar to that of simvastatin $(5 \mu \mathrm{M})$ on the oxLDL-induced MCP-1 and CCR2 expression.

The effects of $\mathrm{ZGH}$ water extract and berberine on oxLDL-induced lipid peroxidation in vitro and DPPH radical generation

Since it is known that oxidative modification of LDL plays a crucial role in the development of atherosclerosis and in cardiovascular disease (Penn and Chisolm, 1996; Ehara et al., 2001), we also examined possible antioxidant activity of ZGH water extract at the concentrations tested for monocyte adhesion. LDL oxidation which was measured by the extent of TBARS was dependent upon LDL concentration, as shown in Fig. 3A, which was prevented by ZGH water extract in a concentrationdependent manner, but a limited degree (Fig. 3B). Such limited effect on LDL oxidation was correlated with its antioxidant ability. As shown in Fig. 3C, neither of the berberine, simvastatin, or low concentration of ZGH water extract showed DPPH radical scavenging activity. Only $10 \mu \mathrm{g} / \mathrm{ml}$ concentration of ZGH water extract showed DPPH radical scavenging activity about $29 \%$ of Vit.C and Vit. E.
(A)

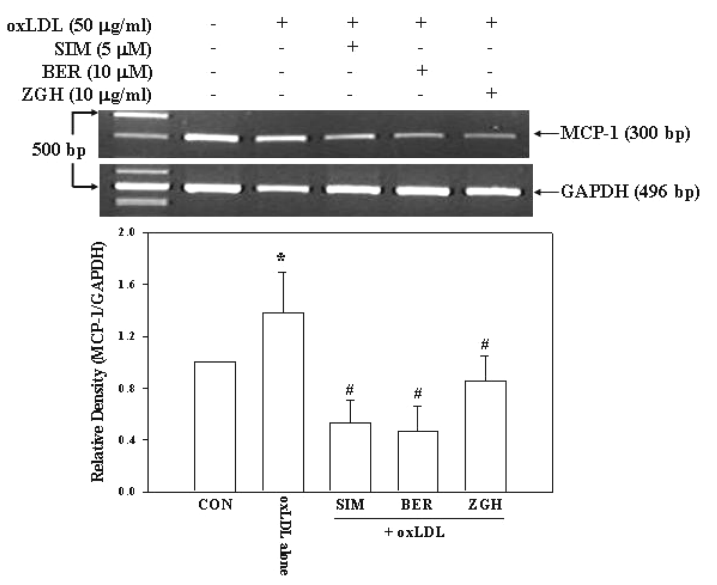

(B)

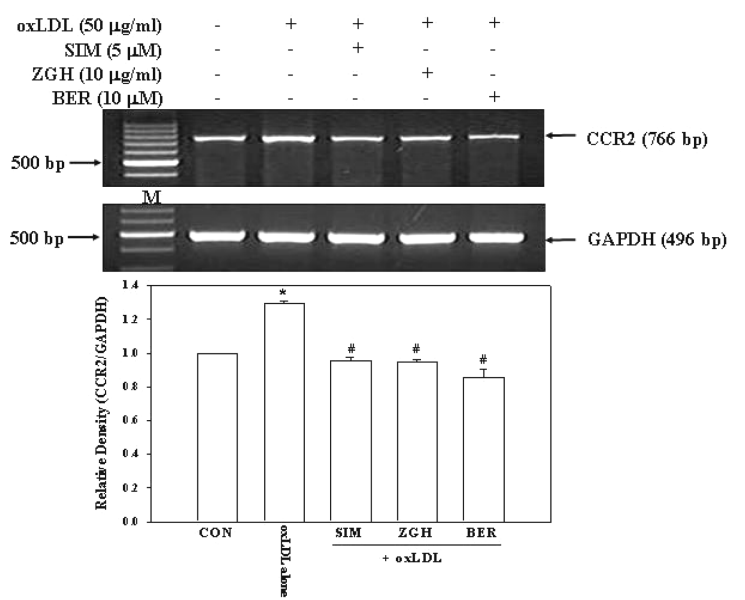

Fig. 2. Inhibitory effects of ZGH water extract and berberine on oxLDL-induced expressions of MCP-1 in HUVECs (A) and CCR2 in U937 cells (B). HUVECs and U937 cells were pretreated with ZGH water extract $(10 \mu \mathrm{g} / \mathrm{ml})$, berberine $(10$ $\mu \mathrm{M})$, or simvastatin $(5 \mu \mathrm{M})$ for $1 \mathrm{~h}$, and then, treated with 50 $\mu \mathrm{g} / \mathrm{ml}$ oxLDL for $3 \mathrm{~h}$. MCP-1 (A) and CCR2 (B) mRNA expression levels were detected in HUVECs and U937 cells (B), respectively, by using RT-PCR. M represents a 100 bp DNA ladder size marker. In the bar graph, the expressions of MCP-1 and CCR2 were normalized to GAPDH using a densitometer. Data are expressed as the mean \pm S.E.M. of three independent experiments. ${ }^{*} P<0.01$ compared to untreated control group. ${ }^{\#} P<0.01$ compared to the oxLDL-treated group.

\section{The effects of ZGH water extract and berberine on Ang} II-induced LOX-1 mRNA expression

Ang II, a potent vasoconstrictor, has been implicated in the progression of cardiovascular diseases and arteriosclerosis (Dzau, 2001). Since it is also known that Ang II increases the expression of LOX-1, we examined any effect of ZGH water 
(A)

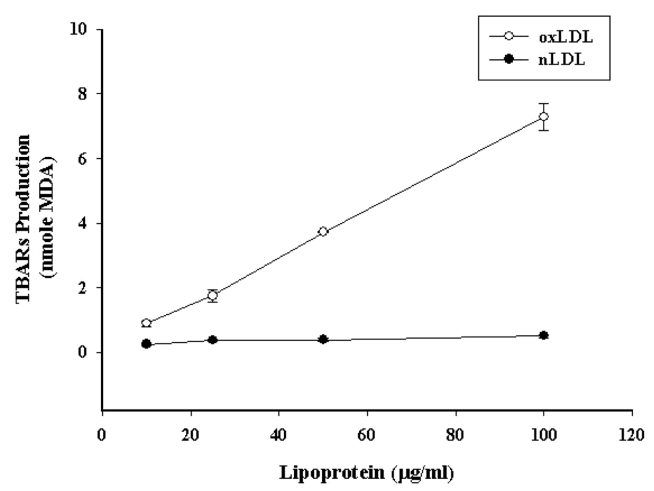

(B)

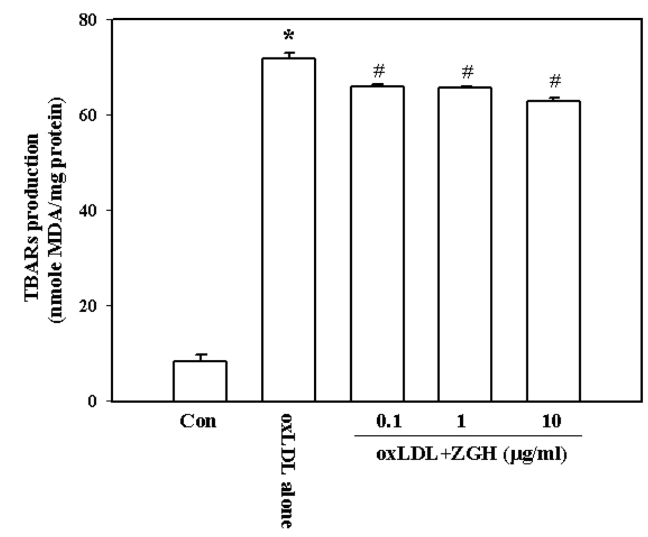

(C)

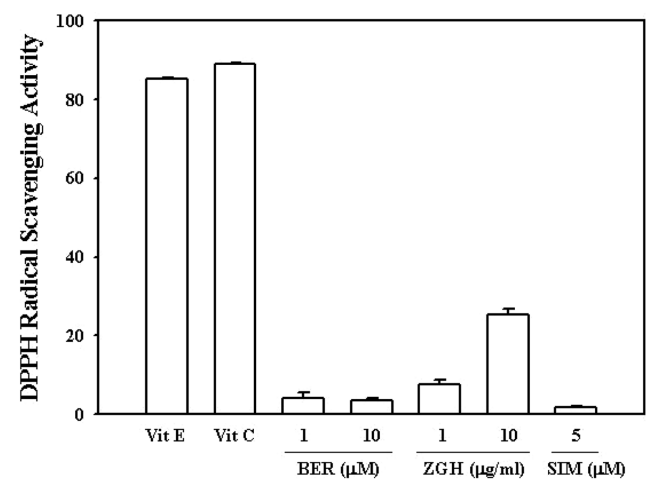

Fig. 3. Effect of $\mathrm{ZGH}$ water extract on the in vitro lipid peroxidation induced by oxLDL $(\mathrm{A}, \mathrm{B})$ and $\mathrm{DPPH}$ radical scavenging activity (C). Lipid peroxidation by oxLDL with $\mathrm{CuSO}_{4}$ was determined by measuring MDA (A). Lipid peroxidation by oxLDL in the absence or presence of $\mathrm{ZGH}$ water extract $(0.1,1$, and $10 \mu \mathrm{g} / \mathrm{ml})$ was measured, and the data points were expressed as nmole MDA (B). The antioxidant activity of ZGH water extract $(1$ and $10 \mu \mathrm{g} / \mathrm{ml})$, berberine $(1$ and $10 \mu \mathrm{M})$, and simvastatin $(5 \mu \mathrm{M})$ was measured by DPPH radical scavenging activity (C). ${ }^{*} P<0.05$, compared to control; ${ }^{\#} P<$ 0.05 , compared to oxLDL-treated group.

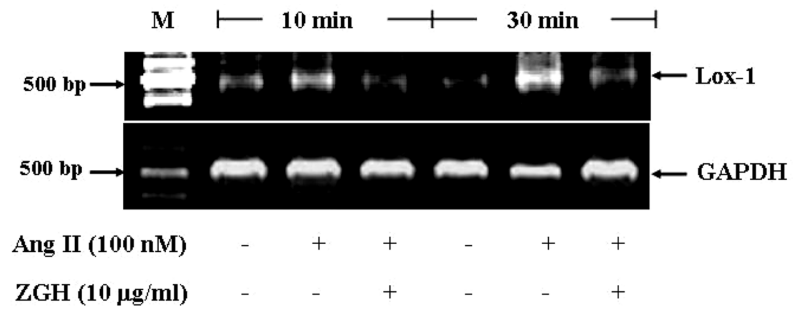

Fig. 4. Effect of ZGH water extract on the Ang II-induced mRNA expression of LOX-1. HUVECs were pretreated with ZGH water extract $(10 \mu \mathrm{g} / \mathrm{ml})$, and then, treated with Ang II $(100 \mathrm{nM})$ for each designated time. LOX-1 mRNA expression was detected by using RT-PCR. The size of RT-PCR product for LOX-1 and GAPDH are 463 bp and $496 \mathrm{bp}$, respectively. M: 100 bp DNA ladder size marker.

extract and berberine on the LOX-1 expression. As shown in Fig. 4, Ang II induced LOX-1 expression, which was significantly inhibited by ZGH water extract and berberine.

\section{DISCUSSION}

The initial phase of the atherosclerosis process is characterized by an increased adhesion of monocytes to vascular endothelium. Such monocyte adhesion requires the expression of specific chemokines such as MCP-1 on endothelial cells. In the present study, we showed ZGH water extract and berberin blocked monocyte adhesion onto HUVECs by suppressing the MCP-1 expression.

It has been shown that CCR2 expression level is as important as MCP-1 expression in the arterial wall for controlling the process of monocyte recruitment (Han et al., 1998; Han et al., 1999; Han et al., 2000). Our result showed that ZGH water extract and berberine inhibited the expression of both MCP-1 and CCR2, suggesting that ZGH water extract and berberine may be effective agents for suppressing oxLDL-induced monocyte recruitment, an initial step in atherogenesis.

Oxidative modification of LDL plays a crucial role in the development of atherosclerosis and in cardiovascular disease (Penn and Chisolm, 1996; Ehara et al., 2001). Also, there is extensive evidence that intracellular redox status is a key modulator of the inflammatory response (Winyard and Blake, 1997), including the modulation of MCP-1 expression (Anjali et al., 1999). However, the inhibition degree of LDL oxidation by ZGH water extract was only about 8 to $12 \%$. Similarly, the ability of ZGH water extract and berberine as an antioxidant was negligible compared to well-known antioxidants such as 
Vit. C and Vit. E.

Ang II is known to be an important factor in atherogenesis. It is also widely appreciated that Ang II and oxLDL are important factors in inducing endothelial dysfunction and injury. Recent studies suggest an interaction between hyperlipidemia, activation of rennin-angiotensin system, and atherosclerotic disease (Nickenig and Bohm, 1997; Keidar et al., 1995; Li et al,. 1999). It has been demonstrated that Ang II induces LOX-1 (Morawietz et al., 1999). LOX-1 is a human endothelial receptor that mediates uptake of oxLDL and structurally distinct from scavenger receptors of macrophages (Sawamura et al., 1997). In the present study, we clearly showed ZGH water extract and berberine suppressed the Ang II-induced expression of LOX-1. We have also previously reported that $\mathrm{ZGH}$ water extract and berberine inhibits Ang II-induced MCP-1 expression and monocyte adhesion through inhibition of reactive oxygen species (Ko et al., 2007). These results indicate that usefulness of ZGH water extract and berberine for the therapy of anti-atherosclerotic disease.

Berberine in Coptis chinensis Franch and evocarpine, a quinolone alkaloid in Evodia officinalis Dode, have also been demonstrated as vasorelaxants (Ko et al., 2000; Yamahara et al., 1988), our results further indicate the potential usefulness of ZGH water extract for the therapy of hypertension-accelerated vascular inflammatory disease. However, this study considers the effect of ZGH in the in vitro vascular inflammation, and thus, it should be followed by in vivo experiments to consolidate the application of ZGH for vascular inflammatory disease.

\section{ACKNOWLEGMENTS}

This work was supported by Korea Research Foundation Grant (KRF-2006-005-J01102).

\section{REFERENCES}

Adams, D. H. and Lloyd, A. R. (1997). Chemokines: leucocyte recruitment and activation cytokines. Lancet. 349, 490-495.

Anjali, D., Huang, X. D. and Jeffrey, S. W. (1999). Intracellular glutathione redox status modulates MCP-1 expression in pulmonary granulomatous vasculitis. Lab Invest. 79, 837-847.

Blois, M. S. (1958). Antioxidant determinations by the use of a stable free radical. Nature 181, 1198-1744

Boring, L., Gosling, J., Cleary, M. and Charo, I. F. (1998). Decreased lesion formation in CCR2)/) mice reveals a role for chemokines in the initiation of atherosclerosis. Nature 394, 894-897.

Bradford, M. (1976). A rapid and sensitive method for the quantitation of microgram quantities of protein utilizing the princi- ple of protein-dye binding. Anal. Biochem. 72, 248-254.

Buege, J. A. and Aust, S. D. (1978). Microsomal lipid peroxidation. Methods Enzymol. 52, 302-310.

Carvalho, D., Savage, C. O., Black, C. M. and Pearson, J.D. (1996). IgG antiendothelial cell autoantibodies from scleroderma patients induce leukocyte adhesion to human vascular endothelial cells in vitro. Induction of adhesion molecule expression and involvement of endothelium-derived cytokines. J. Clin. Invest. 97, 111-119.

Charo, I. F., Myers, S. J., Herman, A., Franci, C., Connolly, A. J. and Coughlin, S.R. (1994). Molecular cloning and functional expression of two monocyte chemoattractant protein 1 receptors reveals alternative splicing of the carboxyl-terminal tails. Proc. Natl. Acad. Sci. U. S. A. 91, 2752-2756.

Dzau, V. J. (2001). Theodore Cooper lecture: tissue angiotensin and pathobiology of vascular disease: a unifying hypothesis. Hypertension 37, 1047-1052.

Ehara, S., Ueda, M., Naruko, T., Haze, K., Itoh, A., Otsuka, M., Komatsu, R., Matsuo, T., Itabe, H., Takano, T., Tsukamoto, Y., Yoshiyama, M., Takeuchi, K., Yoshikawa, J. and Becker, A. E. (2001). Elevated levels of oxidized low density lipoprotein show a positive relationship with the severity of acute coronary syndromes. Circulation 17, 1955-1960.

Han, K. H., Chang, M. K., Boullier, A., Green, S. R., Li, A., Glass, C. K. and Quehenberger, O. (2000). Oxidized LDL reduces monocyte CCR2 expression through pathways involving peroxisome proliferator-activated receptor gamma. J. Clin. Invest. 106, 793-802.

Han, K. H., Han, K. O., Green, S. R. and Quehenberger, O. (1999). Expression of the monocyte chemoattractant protein-1 receptor CCR2 is increased in hypercholesterolemia. Differential effects of plasma lipoproteins on monocyte function. $J$. Lipid Res. 40, 1053-1063.

Han, K. H., Ryu, J., Hong, K. H., Ko, J., Pak, Y. K., Kim, J. B., Park, S. W. and Kim, J. J. (2005). HMG-CoA reductase inhibition reduces monocyte $\mathrm{CC}$ chemokine receptor 2 expression and monocyte chemoattractant protein-1-mediated monocyte recruitment in vivo. Circulation 22, 1439-1447.

Han, K. H., Tangirala, R. K., Green, S. R. and Quehenberger, O. (1998). Chemokine receptor CCR2 expression and monocyte chemoattractant protein-1-mediated chemotaxis in human monocytes. A regulatory role for plasma LDL. Arterioscler. Thromb Vasc Biol. 18, 1983-1991

Hong, Y., Hui, S. C., Chan, T. Y. and Hou, J.Y. (2002). Effect of berberine on regression of pressure-overload induced cardiac hypertrophy in rats. Am. J. Chin. Med. 30, 589-599.

Kaikita, K., Hayasaki, T., Okuma, T., Kuziel, W. A., Ogawa, H. and Takeya, M. (2004). Targeted deletion of CC chemokine receptor 2 attenuates left ventricular remodeling after experimental myocardial infarction. Am. J. Pathol. 165, 439-447.

Keidar, S., Kaplan, M., Hoffman, A. and Aviram, M. (1995). Angiotensin II stimulates macrophage-mediated oxidation of low density lipoproteins. Atherosclerosis 115, 201-215.

Ko, W. H., Yao, X. Q., Lau, C. W., Law, W. I., Chen, Z. Y., Kwok, W., Ho, K. and Huang, Y. (2000). Vasorelaxant and antiproliferative effects of berberine. Eur. J. Pharmacol. 399, 187-196.

Ko, Y. J., Lee, J. S., Park, B. C., Shin, H. M. and Kim, J. A. (2007). Inhibitory effects of Zoagumhwan water extract and berberine on angiotensin II-induced monocyte chemoattractant protein (MCP)-1 expression and monocyte adhesion to endothelial cells. Vascul. Pharmacol. 47, 189-196.

Kong, W., Wei, J., Abidi, P., Lin, M., Inaba, S., Li, C., Wang, Y., 
Wang, Z., Si, S., Pan, H., Wang, S., Wu, J., Wang, Y., Li, Z., Liu, J. and Jiang, J. D. (2004). Berberine is a novel cholesterollowering drug working through a unique mechanism distinct from statins. Nat. Med. 10, 1344-1351.

Kurihara, T. and Bravo, R. (1996). Cloning and functional expression of $\mathrm{mCCR} 2$, a murine receptor for the C-C chemokines JE and FIC. J. Biol. Chem. 271, 11603-11607.

Lau, C. W., Yao, X. Q., Chen, Z. Y., Ko, W. H. and Huang, Y. (2001). Cardiovascular actions of berberine. Cardiovasc. Drug Rev. 19, 234-244.

Lazzarino, D.A., de Diego, M., Hirschman, S.Z., Zhang, K.Y., Shaikh, S., Musi, E., Liaw, L. and Alexander, R.J. (2001). IL-8 and MCP-1 secretion is enhanced by the peptide-nucleic acid immunomodulator, Product $\mathrm{R}$, in U937 cells and primary human monocytes. Cytokine 14, 234-239.

Li, D. Y., Zhang, Y. C., Philips, M. I., Sawamura, T. and Mehta, J. L. (1999). Upregulation of endothelial receptor for oxidized low-density lipoprotein (LOX-1) in cultured human coronary artery endothelial cells by angiotensin II type 1 receptor activation. Circ. Res. 14, 1043-1049.

Morawietz, H., Rueckschloss, U., Niemann, B., Duerrschmidt, N., Galle, J., Hakim, K., Zerkowski, H.R., Sawamura, T. and Holtz, J. (1999). Angiotensin II induces LOX-1, the human endothelial receptor for oxidized low-density lipoprotein. Circulation 31, 899-902.

Navab, M., Imes, S. S., Hama, S. Y., Hough, G. P., Ross, L. A., Bork, R. W., Valente, A. J., Berliner, J. A., Drinkwater, D. C. and Laks, H. (1991). Monocyte transmigration induced by modification of low density lipoprotein in cocultures of human aortic wall cells is due to induction of monocyte chemotactic protein 1 synthesis and is abolished by high density lipoprotein. J Clin Invest. 88, 2039-2046.

Nickenig, G. and Bohm, M. (1997). Regulation of the angiotensin AT1 receptor expression by hypercholesterolemia. Eur. J. Med. Res. 28, 285-289.

Park , B. C., Thapa, D., Lee, Y. S., Kwak, M. K., Lee, E. S., Choi, H. G., Yong, C. S. and Kim, J. A. (2007). 1-furan-2-yl-3- pyridin-2-yl-propenone inhibits the invasion and migration of HT1080 human fibrosarcoma cells through the inhibition of proMMP-2 activation and down regulation of MMP-9 and MT1-MMP. Eur. J. Pharmacol. 19, 193-197.

Penn, M. S. and Chisolm, G. M. (1994). Oxidized lipoproteins, altered cell function and atherosclerosis. Atherosclerosis $\mathbf{1 0 8}$ Suppl, S21-S29.

Ramos, P., Gieseg, S. P., Schuster, B. and Esterbauer, H. (1995). Effect of temperature and phase transition on oxidation resistance of low density lipoprotein. J. Lipid Res. 36, 2113-2128.

Sawamura, T., Kume, N., Aoyama, T., Moriwaki, H., Hoshikawa, H., Aiba, Y., Tanaka, T., Miwa, S., Katsura, Y., Kita, T. and Masaki, T. (1997). An endothelial receptor for oxidized lowdensity lipoprotein. Nature 6, 73-77.

Seino, Y., Ikeda, U., Takahashi, M., Hojo, Y., Irokawa, M., Kasahara, T. and Shimada, K. (1995). Expression of monocyte chemoattractant protein-1 in vascular tissue. Cytokine 7, 575579.

Sica, A., Wang, J. M., Colotta, F., Dejana, E., Mantovani, A., Oppenheim, J. J., Larsen, C. G., Zachariae, C. O. and Matsushima, K. (1990). Monocyte chemotactic and activating factor gene expression induced in endothelial cells by IL-1 and tumor necrosis factor. J. Immunol. 15, 3034-3038.

Takeya, M., Yoshimura, T., Leonald, E. J. and Takahashi, K. (1993). Detection of monocyte chemoattractant protein- 1 in human atherosclerotic lesions by an anti-monocyte chemoattractant protein-1 monoclonal antibody. Hum. Pathol. 24, 534539.

Terkeltaub, R., Boisvert, W. A. and Curtiss, L. K. (1998). Chemokines and atherosclerosis. Curr. Opin. Lipidol. 9, 397-405.

Yamahara, J., Kobayashi, G., Matsuda, H. and Fujimura, H. (1988). The vasorelaxant effect of evocarpine in isolated aortic strips:mode of action. Eur. J. Pharmacol. 155, 139-143.

Yang, Y. Y., Hu, C. J., Chang, S. M., Tai, T. Y. and Leu, S. J. (2004). Aspirin inhibits monocyte chemoattractant protein-1 and interleukin-8 expression in TNF-alpha stimulated human umbilical vein endothelial cells. Atherosclerosis 174, 207-213. 